\title{
Ichnological Research of Silurian-Devonian Strata and the Zoophycos Distribution in the Paraná Basin
}

\author{
Pesquisas icnológicas dos estratos Siluro-Devonianos e a \\ distribuição de Zoophycos na Bacia do Paraná
}

\section{Investigación icnológica de estratos del Siluro-Devónico y distribución de Zoophycos en la Cuenca de Paraná}

\author{
Kevin William Richter \\ https:/ / orcid.org/0000-0002-2576-4117 \\ kevinwilliamrichter@gmail.com \\ Universidade Estadual de Ponta Grossa, UEPG, Ponta Grossa, PR \\ Elvio Pinto Bosetti \\ https:/ / orcid.org/0000-0003-1120-4933 \\ elviobosetti@gmail.com
}

Universidade Estadual de Ponta Grossa, UEPG, Ponta Grossa, PR

Daniel Sedorko

https:/ / orcid.org/0000-0002-9324-3460

sedorko@ufu.br

Universidade Federal de Uberlândia, UFU, Monte Carmelo, MG

\begin{abstract}
The Silurian-Devonian strata of the Paraná Basin (southern Brazil) have a wide variety of ichnofossils. The first records date from the beginning of the last century, with pioneering studies in 1912 addressing the Furnas and Ponta Grossa formations. Significant advances in the ichnological knowledge of these units occurred between the 1980s and 1990s, emphasizing ichnotaxonomic characterizations. These ichnological studies were important for better understanding and describing the main depositional environments, ecological strategies, biostratigraphy, and the relation with the preserved paleofauna. In this contribution, we review this knowledge and analyze the distribution and paleoecological significance of Zoophycos, the most remarkable ichnotaxon in the Lower Paleozoic beds of the Paraná Basin.
\end{abstract}

Keywords: Ichnofossils, Silurian, Devonian, Paraná Basin.

Resumo: Os estratos siluro-devonianos da Bacia do Paraná (sul do Brasil) apresentam grande variedade de icnofósseis. Os primeiros registros datam do início do século passado, com estudos pioneiros em 1912 abordando as formações Furnas e Ponta Grossa. No entanto, avanços significativos no conhecimento icnológico dessas unidades ocorreram entre as décadas de 1980 e 1990, com ênfase nas caracterizações 
icnotaxonômicas. Os estudos icnológicos foram importantes para o entendimento e caracterização dos principais ambientes deposicionais, estratégias ecológicas, bioestratigrafia e relação com a paleofauna preservada. Nessa contribuição, faz-se uma revisão do conhecimento icnológico do Paleozoico inferior da Bacia do Paraná e uma análise da distribuição e do significado paleoecológico de Zoophycos, que configura o mais destacado icnotáxon nesses depósitos.

Palavras chaves: Icnofósseis, Siluriano, Devoniano, Bacia do Paraná.

Resumen: Los estratos siluro-devónicos de la Cuenca de Paraná (sur de Brasil) presentan una gran variedad de trazas fósiles. Los primeros registros datan de principios del siglo pasado, con estudios pioneros en 1912 acerca de las formaciones Furnas y Ponta Grossa. Sin embargo, entre los años 1980 y 1990 se produjeron avances significativos en el conocimiento icnológico de estas unidades, con énfasis en las caracterizaciones icnotaxonómicas. Los estudios icnológicos fueron importantes para el conocimiento y caracterización de los principales ambientes depositacionales, estrategias ecológicas, bioestratigrafía y relación con la paleofauna preservada. El presente estudio consiste en una revisión de la icnología del Paleozoico inferior de la Cuenca de Paraná y un análisis de la distribución y de la importancia paleoecológica de Zoophycos, el más destacado icnotaxón en estos depósitos.

Palabras clave: Traza fósiles, Silúrico, Devónico, Cuenca del Paraná.

\section{INTRODUCTION}

The early records of trace fossils for the Silurian-Devonian strata of Paraná State were made by Oliveira (1912), Clarke (1913), and Lange (1942), with references to the presence of "tubes of worms" for the Furnas and Ponta Grossa formations. However, ichnologic studies in that units were more frequent in the literature between the 1980s and 1990s (Ciguel \& Aceñolaza, 1986; 1989; Campanha, 1985; Fernandes \& Melo, 1985; Assine, 1996; 1999; Fernandes, 1996), although recent studies are available in the literature (Netto, Tognoli, Assine \& Nara, 2014; Sedorko et al., 2017, Sedorko, Bosetti \& Netto, 2018a; Sedorko, Netto \& Savrda 2018b; Sedorko, Netto \& Horodyski, 2018c, 2019; Sedorko et al., 2021).

A particular ichnogenus, Zoophycos Massalongo, 1855, has been reported by several authors for Ponta Grossa Formation (Campanha, 1985; Diniz, 1985; Castro, 1988; Fernandes, 1996; Simões et al., 2000; Sedorko, Bosetti \& Netto, 2018a). Zoophycos is a conspicuous trace fossil in marine deposits from Phanerozoic, with a well-established distribution trend from shallow-marine facies during Paleozoic to deep water in post-Mesozoic strata (Zhang, Fan \& Gong, 2015). This trace fossil was initially identified as a plant (Massalongo, 1855) in the fucoid age of Ichnology, but after, an animal origin was evidenced even that its ethology and mode of production are still a debated topic (Kotake, 1989, 1992; Bromley, 1991; Oliveiro, 2007; Löwemark, 2012). Although the tracemaker and the ethologic class represented by Zoophycos are open questions in Ichnology, the paleoenvironmental distribution is wellestablished for the so-called Zoophycos Group.

Considering that the Paraná Basin preserves important geologic and biologic events from Ordovician to Cretaceous (Milani et al., 2007), we aimed in this study to (i) analyze the advances that ichnological studies had provided for the understanding of the 
Silurian-Devonian deposits in the state of Paraná; and (ii) analyze the Zoophycos distribution in the Paraná Basin (southern Brazil) focusing in its paleoecological significance.

\section{MATERIAL AND METHODS}

Extensive bibliographic research aimed to group studies that report trace fossils in the Paraná State and Zoophycos for Paraná Basin. The distribution of Zoophycos in the Paraná Basin was summarized to identify the geographic and stratigraphic position, represented in the map modified from Milani et al. (2007, Fig. 1). Each point in the map considered the Zoophycos occurrence (Fig. 1B), but density was not considered. The works reporting Spirophyton (Carvalho \& Pinto, 1938 apud Fernandes, 1996; Caputo, 1984 apud Fernandes, 1996) were excluded from this analysis due to the impossibility to access the specimens and lack of illustrations.

\section{GEOLOGICAL SETTING}

The intracratonic Paraná Basin extends from Brazil to Argentina, Paraguay, and Uruguay (Fig. 1A). Its sedimentary filling comprises six supersequences - Rio Ivaí, Paraná, Gondwana I, Gondwana II, Gondwana III, and Bauru (Milani et al., 2007). These supersequences were generated in response to tectonic-eustatic cycles associated with the evolution of the Western Gondwana, deposited from Late Ordovician to Late Cretaceous in several depositional settings mostly controlled by eustatic and subsidence cycles during Silurian to Devonian (see Assine, 1996; Bergamaschi, 1999; Cândido \& Rostirola, 2007; Sedorko, Netto \& Savrda, 2018b; Vargas et al., 2020, for a stratigraphic framework of Paraná Supersequence). Trace fossils are well-distributed along the whole Paraná Supersequence (Sedorko, Netto \& Horodyski, 2019), but Zoophycos is only preserved in Pragian to Eifelian strata (Sedorko, Netto \& Horodyski, 2018c). Regarding lithostratigraphy, this cycle is composed of Furnas and Ponta Grossa formations (sensu Lange \& Petri, 1967; other lithostratigraphic nomenclature is proposed in Grahn, Mendelowicz Mauller, Bergamaschi \& Bosetti, 2013). Assine (1999), based on lithological and stratigraphic aspects, divided the Furnas Formation into three units, naming them as lower, middle, and upper units. The Furnas Formation presents expressions of proximal Cruziana and Skolithos ichnofacies (Sedorko et al., 2017). The Ponta Grossa Formation is traditionally divided into Jaguariaíva, Tibagi, and São Domingos members (Lange \& Petri, 1967) and presents the dominance of archetypal to distal expressions of Cruziana ichnofacies (Sedorko et al., 2019). The Zoophycos distribution in Ponta Grossa Formation was discussed in Sedorko, Netto \& Horodyski (2018c, 2019), and Sedorko et al. (2021). 
Figure 1: Location map of Paraná Group (Paraná Supersequence) and Zoophycos occurrences in Paraná Basin.

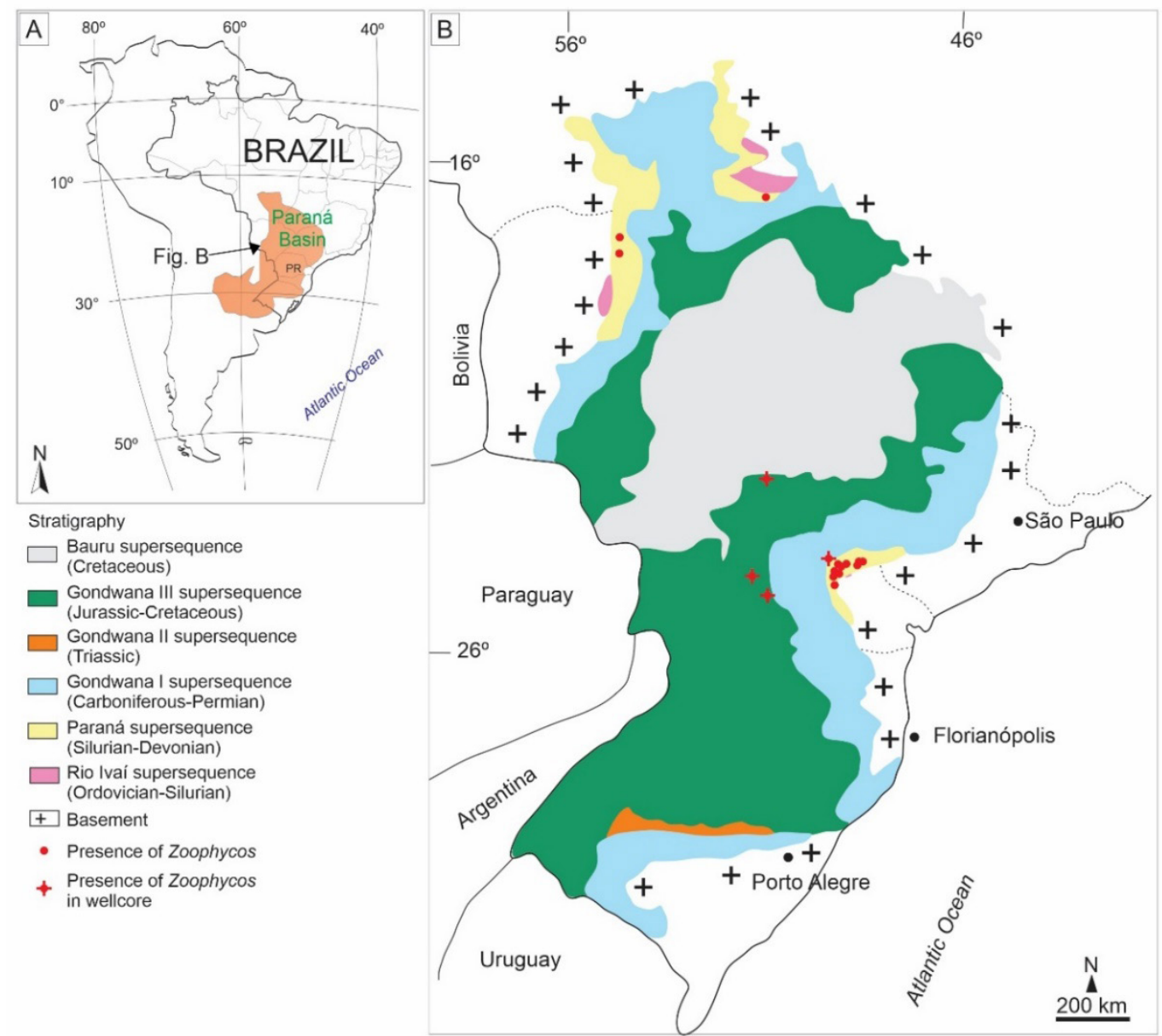

Source: Modified from Milani et al. (2007).

\section{RESULTS AND DISCUSSION}

\section{Furnas Formation}

Sedorko, Netto and Bosetti (2013) presented an overview of trace fossils studies for Paraná Group, demonstrating two main phases: an ichnotaxonomic approach up to the 1990s; and an applied ichnologic approach after the 1990s (mainly as indicators of depositional settings). Under the second approach view, Borghi $(1993 ; 1994)$ reported trace fossils expressing Skolithos and Cruziana ichnofacies for Furnas Formation, corroborated by later studies attesting a shallow marine depositional setting for the trace-fossils bearing levels (Fernandes, 1996; Assine, 1996, 1999). After 2013, Netto et al. (2014) identified the occurrence of dense colonization of Rosselia ichnofabrics in the "Transition Layers" of the Furnas Formation, previously recorded mainly in Cenozoic strata, signalizing the ecological strategies in storm events and a tolerant behavior to stress conditions. Then, Sedorko et al. 
(2017) characterized the ranges with trace fossils with ichnostratigraphic value for Furnas Formation, such as Arthrophycus alleghaniensis, A. brongniartii, and Cruziana acacensis in the lower and middle units. It was possible to insert these strata as Lower Silurian and not Lower Devonian as classically positioned through these ichnotaxa. The upper Furnas unit is inserted in the Lower Devonian by evidence of palynomorphs and macrofossils of vascular plants (Dino \& Rodrigues, 1995; Mussa et al., 1996; Grahn et al., 2013).

Thus, the trace fossils identified for the lower unit are Arenicolites isp., Cruziana isp., Cylindrichnus isp., Didymaulichnus lyelli, Diplocraterion isp., Planolites isp., Palaeophycus isp., Palaeophycus tubularis, Rusophycus isp., Rusophycus acacensis, Skolithos isp., and Thalassinoides isp. (Assine, 1996; 1999; Bergamaschi, 1999; Assine \& Góis, 1996; Ciguel, 1996; Fernandes, 1996; Tognoli, Assine \& Netto, 2002; Netto, Tognoli \& Gandini, 2012; Netto et al., 2014; Sedorko et al., 2017). For the middle unit, the trace fossils identified are Arenicolites isp., Arthrophycus alleghaniensis, A. brongniartii, Cruziana isp., Cruziana acacensis, Didymaulichnus lyelli, Didymaulyponomos rowei, Heimdallia chatwini, Lockeia siliquaria, Psammichnites implexus, Rhizocorallium commune, Rusophycus isp., Rusophycus acacensis, Skolithos isp., and Thalassinoides isp. (Assine, 1996; 1999; Assine \& Góis, 1996; Ciguel, 1996; Fernandes, 1996; Tognolli, Assine \& Netto, 2002; Netto, Tognoli \& Gandini, 2012; 2014; Sedorko et al., 2017). Finally, the strata comprising the upper unit present Cylindrichnus isp., Lockeia isp., Monocraterion isp., Palaeophycus isp., Planolites isp., Rhizocorallium isp., Rosselia socialis, Skolithos isp., Thalassinoides isp., and Teichichnus isp. (Fernandes, 1996; Bergamaschi, 1999; Tognoli, Assine \& Netto, 2002; Netto et al., 2014; Sedorko et al., 2017).

Those trace fossils are expressions of Cruziana and Skolithos ichnofacies, indicating a shallow marine depositional system (Assine, 1996; Sedorko et al., 2017). The relative age assignment for the basal and intermediate intervals as Lower Silurian were only possible using trace fossils with ichnostratigraphic value.

\section{Ponta Grossa Formation}

The Ponta Grossa Formation is characterized as a predominantly shale unit representing marine paleoenvironment, as attested by their rich paleofauna included in the context of the Malvinokaffric Realm (Richter, 1941). When compared to Furnas Formation, trace fossils from these deposits were mostly studied after 2000 (Tognoli et al., 2002; Netto, Tognoli \& Gandini, 2012; Netto et al., 2014; Sedorko, Bosetti \& Netto, 2018a; Sedorko, Netto \& Savrda, 2018b; Sedorko, Netto \& Horodyski, 2018c; 2019; Sedorko et al., 2021; Bosetti et al., 2021), although early studies had been conducted before 2000 (Campanha, 1985; Fernandes, 1996). Recent updates to the Devonian strata of the Paraná State have identified expressions of Glossifungites, Skolithos, and Cruziana ichnofacies (Sedorko, Bosetti \& Netto, 2018a).

The ichnotaxa identified for the Ponta Grossa Formation are Arenicolites isp., Asterosoma isp., Bergaueria isp., Bifungites isp., Bifungites paranaensis, B. cruciformis, Chondrites isp., Cylindrichnus isp., Diplichnites isp., Diplocraterion isp., Heimdallia isp., Helminthopsis isp., Helichodromites isp., Laevicyclus isp., Lingulichnus isp., Lockeia isp., Palaeophycus isp., Phycosiphon isp., Planolites isp., Psammichnites isp., Rhizocorallium commune, Rosselia isp., 
Rosselia socialis, Rusophycus isp., Schaubcylindrichnus isp., Skolithos isp., Taenidium isp., and Zoophycos isp. (Campanha, 1985; Fernandes \& Melo, 1985; Fernandes, 1996; Tognoli, Assine \& Netto, 2002; Bosetti \& Silva, 2009; Carelli \& Borghi, 2011; Netto, Tognoli \& Gandini, 2012; Bosetti, Borghi, Sedorko \& Myszynski Jr, 2017; Bosetti et al., 2021; Sedorko, Bosetti \& Netto, 2018a; Sedorko, Netto \& Savrda, 2018b; Sedorko, Netto \& Horodyski, 2018c).

Recently, Sedorko, Bosetti and Netto (2018a) demonstrated that accurate paleoenvironmental interpretations could be derived through integrated approaches between ichnology, sedimentology, and taphonomy. Analyzing the paleoenvironmental context of a section of the Ponta Grossa Formation, they observed that sets of taphofacies associated with certain ichnofabrics showed variations in paleofauna control, triggered by energy conditions and oxygenation levels due to sea-level changes. In another study, Sedorko, Netto and Savrda (2018b) refined stratigraphic frameworks applying trace fossils data. In the same year, Sedorko et al. (2018d) analyzed a regressive section of the Lower Devonian from the northwest Paraná Basin, demonstrating the dominance of shallower environments compared to the southern part of the Paraná Basin. Later, Sedorko, Netto \& Horodyski (2019) used trace fossils to propose a paleobathymetric curve for the SilurianDevonian strata of the Paraná Basin. Finally, Sedorko et al. (2021) applied ichnology as a relative proxy to understand the impact of the main paleobiological events that led to the decline of the Malvinokaffric Realm in the Paraná Basin. Thus, compared to Furnas Formation, most applied studies on ichnology for Ponta Grossa were conducted after 2000, especially after 2017.

\section{Zoophycos distribution in Paraná Basin}

The most common morphology in the Ponta Grossa Formation is a planar U-shaped, multiple whorl spreiten burrow; however, helical and lobed forms are also preserved, with a maximum of two whorls. Spreite thickness varies from 0.5 to $3.2 \mathrm{~cm}$, and the width of spreite oscillates can reach $50 \mathrm{~cm}$. These morphologies were discussed in Sedorko, Netto and Horodyski (2018c). The first study to apply Zoophycos for paleonvironmental inferences in the Paraná Basin was elaborated by Campanha (1985), interpreting the strata of Ponta Grossa Formation with Zoophycos deposited in offshore settings (Table 1). In the same year, Diniz (1985) reported Zoophycos for several well-cores that sampled Ponta Grossa Formation (Table 1). Castro (1988) also registered Zoophycos in this unit. Fernandes (1996) described different Zoophycos morphologies and expanded the geographic distribution of Zoophycos in Goiás State, besides describing this ichnogenus in Paraná State. Simões et al. (2000) inferred that Zoophycos was responsible for the reorientation of some conularids, and Bosetti, Horodyski, Matsumura and Myszynski Jr. (2013) used Zoophycos to correlate stratigraphic successions in Ponta Grossa city. The stratigraphic control of Zoophycos was presented in Sedorko, Netto \& Horodyski (2018c), demonstrating that this ichnogenus is absent in post-Eifelian beds of the Ponta Grossa Formation. After extensive bibliographic research, only one study reported Zoophycos for non-Devonian strata of the Paraná Basin (Oliveira, 2019). The author analyzed the facies of the Itararé Group, but the illustrated 
specimen referred to as Zoophycos seems to be a Taenidium (Fig. 26 of Oliveira, 2019) by the lack of evident spreite. Thus, Zoophycos occurs exclusively in the Lower-Middle Devonian in Paraná Basin due to environmental control.

Table 1: Studies that described Zoophycos in Paraná Basin.

\begin{tabular}{|c|c|c|c|c|}
\hline Locality & Period & Lithostratigraphic unit & Referred ichnotaxa & Reference \\
\hline Ponta Grossa (PR) & Devonian & Ponta Grossa Formation & Zoophycos & Campanha (1985) \\
\hline $\begin{array}{l}\text { Cuiabá Paulista (SP) } \\
\text { well-core 3-CB-2-SP }\end{array}$ & Devonian & Ponta Grossa Formation & Zoophycos & Diniz (1985) \\
\hline $\begin{array}{l}\text { Chapéu do Sol (PR) } \\
\text { well-core 1-CS-2-PR }\end{array}$ & Devonian & Ponta Grossa Formation & Zoophycos & Diniz (1985) \\
\hline $\begin{array}{l}\text { Roncador (PR) well- } \\
\text { core 1-RO-1-PR }\end{array}$ & Devonian & Ponta Grossa Formation & Zoophycos & Diniz (1985) \\
\hline Ponta Grossa (PR) & Devonian & Ponta Grossa Formation & Zoophycos & Castro (1988) \\
\hline Amorinópolis (GO) & Devonian & Ponta Grossa Formation & Zoophycos ichnosp. 1 & Fernandes (1996) \\
\hline Ponta Grossa (PR) & Devonian & Ponta Grossa Formation & $\begin{array}{l}\text { Zoophycos ichnosp. } \\
\text { indet }\end{array}$ & Fernandes (1996) \\
\hline Ponta Grossa (PR) & Devonian & Ponta Grossa Formation & Zoophycos ichnosp. 2 & Fernandes (1996) \\
\hline Jaguariaíva (PR) & Devonian & Ponta Grossa Formation & $\begin{array}{l}\text { Zoophycos ichnosp. } \\
\text { indet }\end{array}$ & Fernandes (1996) \\
\hline Jaguariaíva & Lower Devonian & Ponta Grossa Formation & $\begin{array}{l}\text { Zoophycos ichnosp. } \\
\text { indet }\end{array}$ & Simões et al. (2000) \\
\hline Ponta Grossa (PR) & Devonian & Ponta Grossa Formation & Zoophycos & $\begin{array}{l}\text { Abelha Borghi \& } \\
\text { Fernandes (2007) }\end{array}$ \\
\hline Ponta Grossa (PR) & Devonian & Ponta Grossa Formation & Zoophycos & $\begin{array}{l}\text { Netto, Tognoli \& } \\
\text { Gandini (2012) }\end{array}$ \\
\hline Ponta Grossa (PR) & Lower Devonian & Ponta Grossa Formation & Zoophycos isp. & Bosetti et al. (2013) \\
\hline Tibagi (PR) & Lower Devonian & Ponta Grossa Formation & Zoophycos isp. & $\begin{array}{l}\text { Sedorko, Bosetti \& } \\
\text { Netto, (2018a) }\end{array}$ \\
\hline Tibagi (PR) & $\begin{array}{l}\text { Lower-Middle } \\
\text { Devonian }\end{array}$ & Ponta Grossa Formation & Zoophycos isp. & $\begin{array}{l}\text { Sedorko, Netto \& } \\
\text { Savrda }(2018 b)\end{array}$ \\
\hline Arapoti (PR) & Lower Devonian & Ponta Grossa Formation & Zoophycos isp. & $\begin{array}{l}\text { Sedorko, Netto \& } \\
\text { Savrda (2018b) }\end{array}$ \\
\hline Tibagi (PR) & $\begin{array}{l}\text { Lower-Middle } \\
\text { Devonian }\end{array}$ & Ponta Grossa Formation & Zoophycos isp. & $\begin{array}{l}\text { Sedorko, Netto \& } \\
\text { Horodyski (2018c) } \\
\end{array}$ \\
\hline Rio Negro (MS) & Lower Devonian & Ponta Grossa Formation & Zoophycos isp. & $\begin{array}{l}\text { Sedorko et al. } \\
(2018 d)\end{array}$ \\
\hline Tibagi (PR) & $\begin{array}{l}\text { Lower-Middle } \\
\text { Devonian }\end{array}$ & Ponta Grossa Formation & Zoophycos isp. & $\begin{array}{l}\text { Sedorko, Netto \& } \\
\text { Horodyski (2019) } \\
\end{array}$ \\
\hline Tibagi (PR) & $\begin{array}{l}\text { Lower-Middle } \\
\text { Devonian }\end{array}$ & Ponta Grossa Formation & Zoophycos isp. & Sedorko et al. (2021) \\
\hline
\end{tabular}

Zoophycos in Ponta Grossa Formation is a common component of Cruziana ichnofacies in Pragian-Eifelian deposits (Table 2) but can express archetypal or distal conditions within this ichnofacies. When representing archetypal conditions, Zoophycos is mostly associated with Asterosoma, Teichichnus, Planolites, Palaeophycus, Schaubcylindrichnus, Rosselia, Cylindrichnus, Chondrites, and Phycosiphon. Zoophycos expressing distal conditions occurs associated with Chondrithes, Phycosiphon, and, less common, Helichodromites. The Zoophycos ichnofacies is restrict to post-Mesozoic deposits (Zhang, Fan \& Gong, 2015), not occurring in Paraná Basin. 
Table 2: List of Zoophycos occurrences in Ponta Grossa Formation.

\begin{tabular}{|c|c|c|c|}
\hline Age & Locality (coordinates) & Ichnofacies & Reference \\
\hline Pragian & \begin{tabular}{|l} 
Tibagi - PR, portal da cidade \\
$(-24.52766964493291,-50.39955964002155)$
\end{tabular} & Archetypal Cruziana & $\begin{array}{l}\text { Sedorko, Netto \& Savrda } \\
(2018 b)\end{array}$ \\
\hline Pragian-Emsian & $\begin{array}{l}\text { Tibagi - PR, Arroio São Domingos } \\
(-24.51186960834,-50.42229237066247)\end{array}$ & Archetypal Cruziana & $\begin{array}{l}\text { Sedorko, Netto \& Savrda } \\
(2018 b)\end{array}$ \\
\hline Pragian-Emsian & \begin{tabular}{|l|} 
Tibagi - PR, acima arroio São Domingos \\
$(-24.51429274382312,-50.428404618755074)$
\end{tabular} & Archetypal Cruziana & $\begin{array}{l}\text { Sedorko, Netto \& Savrda } \\
(2018 b)\end{array}$ \\
\hline Pragian-Emsian & $\begin{array}{l}\text { Arapoti - PR, PR 092, entrada CEEP } \\
(-24.168075299799053,-49.80142437022979)\end{array}$ & Archetypal Cruziana & This study \\
\hline Pragian-Emsian & $\begin{array}{l}\text { Arapoti - PR, CEEP } \\
(-24.193704213996508,-49.78393796069782)\end{array}$ & Archetypal Cruziana & $\begin{array}{l}\text { Sedorko, Netto \& Savrda } \\
(2018 b)\end{array}$ \\
\hline Pragian-Emsian & $\begin{array}{l}\text { Jaguariaíva - PR, trilho } \\
(-24.241278747041477,-49.71778874523683)\end{array}$ & Archetypal Cruziana & Simões et al. (2000) \\
\hline Pragian-Emsian & $\begin{array}{l}\text { Rio Negro - MS, estrada ponte nova } \\
(-19.43705405108732,-55.00280606955078)\end{array}$ & Archetypal Cruziana & Sedorko et al. (2018d) \\
\hline Emsian & $\begin{array}{l}\text { Tibagi - PR, entrada da cidade } \\
(-24.55672958704829,-50.45546641393211)\end{array}$ & Archetypal Cruziana & $\begin{array}{l}\text { Sedorko, Netto \& Savrda } \\
(2018 b)\end{array}$ \\
\hline Emsian & $\begin{array}{l}\text { Tibagi - PR, BR 153, km } 211 \\
(-24.56454774785814,-50.45431255274105)\end{array}$ & Archetypal Cruziana & $\begin{array}{l}\text { Sedorko, Bosetti \& Netto } \\
\text { (2018a), Sedorko, Netto \& } \\
\text { Savrda (2018b) }\end{array}$ \\
\hline Emsian & $\begin{array}{l}\text { Tibagi - PR, BR 153, km } 211 \\
(-24.56454774785814,-50.45431255274105)\end{array}$ & Distal Cruziana & $\begin{array}{l}\text { Sedorko, Bosetti, \& Netto } \\
\text { (2018a), Sedorko, Netto \& } \\
\text { Savrda (2018b) }\end{array}$ \\
\hline Emsian & $\begin{array}{l}\text { Piraí do Sul - PR, Rio Guaricanga } \\
(-24.3588600872764,-50.09816506919163)\end{array}$ & Archetypal Cruziana & This study \\
\hline Emsian & $\begin{array}{l}\text { Piraí do Sul - PR, Fazenda Mutuca } \\
(-24.28871509229243,-50.088358999162374)\end{array}$ & Archetypal Cruziana & This study \\
\hline Emsian & $\begin{array}{l}\text { Ponta Grossa - PR, Curva } 1 \\
(-25.063786583020153,-50.132983806921615)\end{array}$ & Archetypal Cruziana & Bosetti et al. (2013) \\
\hline Emsian & $\begin{array}{l}\text { Ponta Grossa - PR, UEPG } \\
(-25.0897755824982,-50.108767653642765)\end{array}$ & Archetypal Cruziana & This study \\
\hline Emsian & $\begin{array}{l}\text { Ponta Grossa - PR, Volsul } \\
(-25.0507682638905,-50.17527589768459)\end{array}$ & Archetypal Cruziana & This study \\
\hline Emsian-Eifelian & $\begin{array}{l}\text { Tibagi - PR, BR 153, km } 214 \\
(-24.58497860474662,-50.43713745137998)\end{array}$ & Archetypal Cruziana & $\begin{array}{l}\text { Sedorko, Netto \& Savrda } \\
\text { (2018b), Sedorko, Netto \& } \\
\text { Horodyski (2018c) }\end{array}$ \\
\hline Emsian-Eifelian & \begin{tabular}{|l|} 
Palmeira - PR, Rio Caniú \\
$(-25.309387530212355,-50.091613307979074)$
\end{tabular} & Archetypal Cruziana & $\mathrm{Ng}(2013)$ \\
\hline Emsian-Eifelian & $\begin{array}{l}\text { Rio Verde do Mato Grosso - MS, MS } 29 \\
(-18.926181318927952,-54.83969733553473)\end{array}$ & Archetypal Cruziana & $\begin{array}{l}\text { Scheffler, Silva \& Sedorko } \\
\text { (2020); Sedorko et al. (2021) }\end{array}$ \\
\hline Emsian-Eifelian & $\begin{array}{l}\text { Coxim, Taquari river } \\
(-18.36351069876289,-54.61197543995809)\end{array}$ & Archetypal Cruziana & This study \\
\hline
\end{tabular}

The Phanerozoic distribution of Zoophycos is hypothesized to have been mostly controlled by the distribution of food resources. The "first bloom" of Zoophycos occurred during Lower Devonian, linked to the plant diversification that might have increased the availability of organic matter in shallow seas (Zhang, Fan \& Gong, 2015). Coincidentally, in the Paraná Basin, the most basal Zoophycos occurs few meters above the first land plants found in the basin (Cooksonia sp.), corroborating this control. The Zoophycos is a stenohaline trace fossil, being preserved in fully marine facies since the Cambrian (Zhang, Fan \& Gong, 2015). Considering that unequivocal Zoophycos are preserved only in the Lower-Middle 
Devonian of the Paraná Basin, this ichnogenus can be regarded as a biomarker of optimum marine settings for the Paraná Basin. The absence of Zoophycos in Ordovician-Silurian marine deposits (i.e., Alto Garças, Iapó, Vila Maria, and Furnas formations) might be related to low productivity rates, considering that the distribution of Zoophycos throughout Phanerozoic was controlled by the disposition of food within substrates (Kotake, 2014; Zhang, Fan \& Gong, 2015; Sedorko, Netto \& Horodyski, 2018c). The worldwide bloom of Zoophycos during the Devonian is well documented in the Paraná Basin (Ponta Grossa Formation). However, its occurrence decreases until disappearance after the plant diversification in Middle Devonian, suggesting changes in the basin configuration (Vargas et al., 2020; Sedorko et al., 2021). Zoophycos is virtually absent in post-Eifelian strata, reflecting impacted, and later, absence of marine conditions represented in upper units. This distribution follows paleogeographic reconstructions that assume the Paraná Basin as a gulf opened to the Panthalassa Sea during the Devonian (Milani et al., 2007).

\section{SUMMARY}

After earlier reports from the beginning of the last century, trace fossil studies had an exclusively ichnotaxonomic approach, with most studies focusing on Furnas Formation up to the 1990s. Trace fossils were decisive in better understanding the depositional settings represented by the Furnas Formation deposits and determining a Lower Silurian age for its lower and middle units. Nowadays, most ichnologic studies have been focused on the Ponta Grossa Formation ichnofauna, using trace fossils as indicators of depositional settings and for paleobiological, paleoecological, and taphonomic interpretations. Only Ponta Grossa Formation preserves unequivocal Zoophycos in the whole Paraná Basin. This ichnogenus is restricted to marine facies since Cambrian; thus, this distribution highlights the optimal marine conditions represented during Devonian in the Paraná Basin.

\section{ACKNOWLEDGMENTS}

D. Sedorko thanks to the Brazilian Scientific and Technological Research Council - CNPq for the post-doc fellowship (proc. 159548/2018-7). The authors thanks Renata G. Netto for discussions and language revision.

\section{REFERENCES}

Abelha, M., Borghi, L., \& Fernandes, A.C.S. (2007). Análise Icnológica da Formação Ponta Grossa (Devoniano) em Afloramentos da Borda Leste da Bacia do Paraná. Jornada Giulio Massarani de Iniciação Científica, Artística e Cultural da UFRJ, 28, Rio de Janeiro, RJ, Brasil.

Assine, M.L. (1996). Aspectos da estratigrafia das sequências pré-carboníferas da Bacia do Paraná no Brasil. Tese de Doutorado. Universidade de São Paulo, São Paulo, SP, Brasil. Recuperado de https:/ teses.usp.br/teses/ disponiveis/44/44136/tde-10112015-154800/pt-br.php 
Assine, M.L., \& Góis, J.R. (1996). Traços fósseis de trilobita na Formação Furnas, Bacia do Paraná, Brasil. Anais do Simpósio Sulamericano do Siluro-Devoniano. 1, Ponta Grossa, PR, Brasil. pp. 371-373.

Assine, M.L. (1999). Fácies, icnofósseis, paleocorrentes e sistemas deposicionais da Formação Furnas no flanco Sudeste da Bacia do Paraná. Revista Brasileira de Geociências, 29(3), 357-370.

Bergamaschi, S. (1999). Análise estratigráfica do Siluro-Devoniano (formações Furnas e Ponta Grossa) da Sub-bacia de Apucarana, Bacia do Paraná, Brasil. Tese de Doutorado. Universidade de São Paulo, USP, São Paulo, SP, Brasil. Recuperado de https:/ / teses.usp.br/teses/disponiveis/44/44136/tde-18112015-101431/pt-br.php

Borghi, L. (1993). Caracterização e análise faciológicas da Formação Furnas em afloramentos do bordo leste da Bacia do Paraná. Dissertação de Mestrado. Universidade Federal do Rio de Janeiro, UFRJ, Rio de Janeiro, RJ, Brasil.

Borghi, L. (1994). Icnofácies da Formação Furnas no estado do Paraná. Anais da Academia Brasileira de Ciências, 66(1), 121.

Bosetti, E.P., \& Silva, R.C. (2009). Primeira ocorrência de Phycosiphon Von Fischer-Ooster, 1858 na Formação Ponta Grossa (Devoniano, Bacia do Paraná) e considerações sobre mudanças ecológicas na passagem Eifeliano-Givetiano. Anais da reunião anual da Sociedade Brasileira de Paleontologia - PALEO. Curitiba, PR, Brasil, 11. p. 10.

Bosetti, E.P., Horodyski, R.S., Matsumura, W.M.K., Myszynski Jr., L.J., \& Sedorko, D. (2013). Análise estratigráfica e tafonômica da sequencia Neopraguiana - eoemsiana do setor nordeste do sítio urbano de Ponta Grossa, Paraná. Brasil. Terr@ Plural, 7, 145-168.

Bosetti, E.P., Borghi, L., Sedorko, D., \& Myszynski Jr., L.J.M. (2017). Fósseis e icnofósseis da Formação Ponta Grossa (Devoniano) na região de Arapoti (PR). Anais do Congresso Brasileiro de Paleontologia, 25. p. 50.

Bosetti, E.P., Netto, R.G., Tognoli, F.M.W., Sedorko, D., \& Matsumura, W.M.K. (2021). Continental input on shelfal deposits unveiled by integration of ichnology, sedimentology, and taphonomy: A case study in givetian beds of the Paraná basin, Brazil. Journal of South American Earth Sciences, 110, 1-12.

Bromley, R.G. (1991). Zoophycos: strip mine, refuse dump, cache or sewage farm? Lethaia, 24, 460-462.

Campanha, V.A. (1985). O significado do icnofóssil Zoophycos na sedimentação da Formação Ponta Grossa (D) Bacia do Paraná. Anais da Academia Brasileira de Ciências, 57(1), 116.

Cândido, A.G., \& Rostirola, S.P. (2007). Análise de fácies e revisão da estratigrafia de sequências da Formação Ponta Grossa, Bacia do Paraná - ênfase nos arenitos do Membro Tibagi. Bol. Geociencias Petrobras ,15, 45-62.

Carelli, T.G., \& Borghi, L. (2011). Caracterização de Microfácies Sedimentares em Folhelhos da Formação Ponta Grossa (Devoniano) na Borda Leste da Bacia do Paraná. Anuário do Instituto de Geociências, 34(2),84-104.

Castro, J.C. de. (1988). Sedimentology. stratigraphy and paleontology of the Gondwana sequence of the Parana Basin. International Gondwana Symposium, 17, São Paulo, SP, Brasil. Guidebook. Excursion A2 (p. 100).

Ciguel, J.H.G \& Aceñolaza, F.G. (1986). Icnologia da Formação furnas (Paleozoico Médio), Bacia do Paraná. Anais da Academia Brasileira de Ciências, 58(4), 595-596.

Ciguel, J.H.G., \& Aceñolaza, F.G. (1989). Conosthicus na Formação Furnas (flanco oriental) no estado do Paraná. Anais do Congresso brasileiro de Paleontologia, 11,. 13-14.

Ciguel, J.H.G. (1996). Os icnofósseis da localidade de Sitio Cercado, estado do Paraná, Brasil - Formação Furnas. (Siluriano-Devoniano), flanco oriental da Bacia do Paraná. Anais do Simpósio Sulamericano do SiluroDevoniano. 1, Ponta Grossa, PR, Brasil. 319-335.

Clarke, J.M. (1913). Fósseis devonianos do Paraná. Monografia do serviço geológico e mineralógico do Brasil.A Diniz, M.N. (1985). Interpretação ambiental da Formação Ponta Grossa na parte central da Bacia do Paraná Um estudo de subsuperfície. Dissertação de Mestrado em Paleontologia e Estratigrafia. Universidade de São Paulo, USP, São Paulo, SP, Brasil. Recuperado de https:/ / www.teses.usp.br/teses/disponiveis/44/44132/ tde-28092015-102501/pt-br.php

Dino, R. \& Rodrigues, M.A.C. (1995). Palinomorfos eodevonianos da Formação Furnas, Bacia do Paraná. Anais da Academia Brasileira de Ciências, 67, 107-116. 
Fernandes, A.C.S. \& Melo, J.H.G. (1985). Ocorrência do icnogênero Bifungites na Formação Ponta Grossa, Devoniano do estado do Paraná. Anais da Academia Brasileira de Ciências, 57(2), 203-207.

Fernandes, A.C.S. (1996). Conteúdo icnológico das Formações Ordoviciano-Devoniano da Bacia do Paraná, Brasil. Tese de Doutorado em Paleontologia. Universidade Federal do Rio de Janeiro, UFRJ, Rio de Janeiro, RJ, Brasil.

Grahn, Y., Mendelowicz Mauller, P.M., Bergamaschi, S., \& Bosetti, E.P. (2013). Palynology and sequence stratigraphy of three Devonian rock units in the Apucarana Subbasin (Paraná Basin, south Brazil): additional data and correlation. Review of Palaeobotany and Palynology, 198, 27-44.

Kotake, N. (1989). Paleoecology of the Zoophycos producers. Lethaia, 22, 327-341.

Kotake, N. (1992). Deep-sea echiurans: possible producers of Zoophycos. Lethaia, 25, 311-316.

Kotake, N. (2014). Changes in lifestyle and habitat of Zoophycos-producing animals related to evolution of phytoplankton during the Late Mesozoic: geological evidence for the 'benthic-pelagic coupling model'. Lethaia, 47, 165-175.

Lange, F.W. (1942). Restos vermiformes do arenito das Furnas. Arquivos do Museu Paranaense, 2(1), 3-8.

Lange, F.W., \& Petri, S. (1967). The Devonian of the Paraná Basin. Boletim Paranaense de Geociências, $(21 / 22), 5-55$.

Löwemark, L. (2012). Ethological analysis of the trace fossil Zoophycos: hints from the Arctic Ocean. Lethaia, 45, 290-298.

Massalongo, A. (1855). Zoophycos, novum genus Plantarum fossilium. Antonellianis, 45-52.

Milani, E.J., Melo, J.H.G., Souza, P.A., Fernandes, L.A., \& França, A.B. (2007). Rochas geradoras e rochasreservatório da Bacia do Paraná, faixa oriental de afloramentos, Estado do Paraná. Boletim de Geociências da Petrobrás, 15,135-162.

Mussa, D., Borghi, L., Bergamaschi, S., Schubert, G., Pereira, E., \& Rodrigues, M.A.C. (1996). Estudo preliminar da tafoflora da Formação Furnas, bacia do Paraná, Brasil: Anais da Academia Brasileira Ciências, 68, 65-89.

Netto, R.G., Tognoli, F.M.W., \& Gandini, R. (2012). Ichnology of the phanerozoic deposits of southern Brazil: sinthetic review. In Netto, R.G., Carmona, N.B., \& F.M.W. Tognoli (Orgs.). Ichnology Of Latin America: Selected Papers. Monografias da Sociedade Brasileira de Paleontologia, (2, pp. 37-68).

Netto, R.G., Tognoli, F.M.W., Assine, M.L., \& Nara, M. (2014). Crowded Rosselia ichnofabric in the Early Devonian of Brazil: An example of strategic behavior. Palaeogeography, Palaeoclimatology, Palaeoecology, 395, 107-113.

$\mathrm{Ng}$, C. (2013). Faciologia, considerações bioestratigráficas e paleoambientais da Formação Ponta Grossa emafloramentos do flanco leste da Subbacia de Apucarana, Devoniano da Bacia do Paraná. Dissertação de Mestrado em Geologia. Universidade Federal do Paraná, UFPR, Curitiba, PR, Brasil. Recuperado de https://acervodigital.ufpr. br/bitstream/handle/1884/32024/R\%20-\%20D\%20-\%20CHRISTIANO\%20NG.pdf?sequence=1

Oliveira, E.P. (1912). O terreno Devoniano do sul do Brasil. Annaes da Escola Minas de Ouro Preto, 14, 31-41.

Oliveira, V. (2019). Evolução paleoambiental e estratigráfica do Grupo Itararé (Bacia do Paraná) região de Presidente Getúlio, Santa Catarina. Trabalho de Conclusão de Curso (Graduação em Geologia). Universidade Federal de Santa Catarina, UFSC, Florianópolis, SC, Brasil.

Oliveiro, D. (2007). Zoophycos and the role of type specimens in ichnotaxonomy. In W. Miller III (Ed). Trace Fossils Concepts, Problems, Prospects. (cap. 13, pp.219-2310. Amsterdam: Elsevier Science.

Richter, R. (1941). Devon. Geologische Jahresberichte, 31-43.

Scheffler, S.M., Silva, R.C., \& Sedorko, D. (2020). O Devoniano no estado do Mato Grosso do Sul, Brazil: nova área de distribuição e presença de típica fauna malvinocáfrica. Estudos Geológicos, 30(2), 38-76.

Sedorko, D., Netto, R.G., \& Bosetti, E.P. (2013). Paleoicnologia do Siluro-Devoniano do estado do Paraná e a obra de John Mason Clarke. Terr@Plural, 7, 59-73. 
Sedorko, D., Netto, R.G., Savrda, C.E., Assine, M.L., \& Tognoli, F.W.M. (2017). Chronostratigraphy and environment of Furnas Formation by trace fossil analysis: Calibrating the lower Paleozoic Gondwana realm in the Paraná Basin (Brazil). Palaeogeography, Palaeoclimatology, Palaeoecology, 487, 307-320.

Sedorko, D., Bosetti, E.P., \& Netto, R.G. (2018a). An integrative ichnological and taphonomic approach in a transgressive-regressive cycle: a case study from Devonian of Paraná Basin, Brazil. Lethaia, 51, 15-34.

Sedorko, D., Netto, R.G., \& Savrda, C.E. (2018b). Ichnology applied to sequence stratigraphic analysis of Siluro-Devonian mud-dominated shelf deposits, Paraná Basin, Brazil. Journal of South American Earth Sciences, 83, 81-95.

Sedorko, D., Netto, R.G., \& Horodyski, R.S. (2018c). A Zoophycos carnival in Devonian beds: Paleoecological, paleobiological, sedimentological, and paleobiogeographic insights. Paleogeography, Palaeoclimatology, Palaeoecology, 507, 188-200. doi: 10.1016/j.palaeo.2018.07.016

Sedorko, D., Bosetti, E.P., Ghilardi, R.P., Myszynski Jr., L.J., Silva, R.C. \& Scheffler, S.M. (2018d). Paleoenvironments of a regressive Devonian section from Paraná Basin (Mato Grosso do Sul state) by integration of ichnologic, taphonomic and sedimentologic analyses. Braz. J. Geol., 48(4), 805-820. https:// doi.org/10.1590/2317-4889201820180021.

Sedorko, D., Netto, R.G., \& Horodyski, R.S. (2019). Tracking Silurian-Devonian events and paleobathymetric curves by ichnologic and taphonomic analyzes in the southwestern. Gondwana. Global and Planetary Change, $179,43-56$.

Sedorko, D., Netto, R.G., Scheffler, S.M., Horodyski, R.S., Bosetti, E.P., .GhilardI, R.P., ... \& Myszynski Jr., L.J. (2021). Paleoecologic trends of Devonian Malvinokaffric fauna from the Paraná Basin as evidenced by trace fossil. Journal of South American Earth Sciences, 109, 1-14.

Simões, M.G., Mello, L.H.C., Rodrigues, S.C., Moraes Leme, J., \& Marques, A. C. (2000). Conulariid taphonomy as a tool in paleoenviron mental analysis. Rev. Bra. Geoc. 30, 757-762.

Tognoli, F.M.W., Assine, M.L., \& Netto, R.G. (2002). Roteiro Icnológico do Grupo Paraná [Folheto]. Rio Claro: UNESP. 27p.

Vargas, M.R., Silveira, A.S., Bressane, A., D'Ávila, R.S.F., Faccion, J.E., \& Paim, P.S.G. (2020). The Devonian of the Paran'a basin, Brazil: sequence stratigraphy, paleogeography, and SW Gondwana interregional correlations. Sediment. Geol., 408, 105768.

Zhang, L., Fan, R. \& Gong, Y. (2015). Zoophycos macroevolution since 541 Ma. Sci. Rep., 5 (14954), 1-10. https://doi.org/10.1038/srep14954.

Data de submissão: 21/jul./2021

Data de aceite: 30/ago./2021 